Hanna Mamzer, Magdalena Anita Gajewska, Łucja Lange

Uniwersytet im. Adama Mickiewicza w Poznaniu, Uniwersytet Gdański, Uniwersytet Łódzki

\title{
Jak rozumieć relacje międzygatunkowe?
}

\section{Wprowadzenie}

Podejmowanie analizy relacji międzygatunkowych obserwować można nie tylko w socjologii najnowszej, ale także w koncepcjach uznawanych już za klasyczne (np. w nurcie interakcjonizmu symbolicznego), jednak dopiero ostatnie pięćdziesięciolecie przyniosło dynamiczne przemiany dyskusji o stosunku ludzi do innych istot żywych. Pojawiające się stopniowo wątki domagają się podjęcia głębszej refleksji tym bardziej, że wprowadzanie nazw nowych subdyscyplin w naukach społecznych i humanistycznych ujawnia dyskusyjność pojęć używanych w innych dyscyplinach lub też stosowanych potocznie i zrozumiałych w codziennej praktyce językowej. Okazuje się też, że wobec analizowania nowych pól badawczych pojęcia te wymagają namysłu, analizy i ostatecznie doprecyzowania. W tym kontekście wyzwaniem stało się sprecyzowanie znaczenia terminu „relacje międzygatunkowe”.

Termin „relacja” w potocznym znaczeniu jest zrozumiały. W zakresie humanistyczno-społecznych analiz relacji międzygatunkowych pojęcie to jawi się jednak w wielu zróżnicowanych odcieniach i prowokuje do wielopoziomowych analiz, które ukazują złożoność percepcji terminu, a co za tym idzie - całego zjawiska. Niezależnie od tego, że nie ma jednej obowiązującej definicji relacji międzygatunkowych, warto pochylić się nad sposobami rozumienia tego określenia. 
Opisywanie relacji międzygatunkowych na gruncie ekologii i biologii jest znacznie bardziej precyzyjne niż w naukach społecznych z powodu wykorzystywania biologicznych definicji określających stosunki zachodzące pomiędzy przedstawicielami różnych gatunków. Definicje te bazują na określaniu zysków, jakie czerpią strony (lub strona), oraz kosztów, jakie strony muszą ponosić. Relacje międzygatunkowe opisuje się zatem jako: nieantagonistyczne (symbioza, protokooperacja, komensalizm) i antagonistyczne (konkurencja, pasożytnictwo, amensalizm, allelopatia, drapieżnictwo). Trudność zastosowania owych kategorii do analiz relacji gatunku ludzkiego z jego otoczeniem przyrodniczym wynika przede wszystkim stąd, że tradycja myślenia o ludziach i otoczeniu przyrodniczym nakazuje rozdzielać to, co ludzkie, i to, co zwierzęce. Trudno zatem przykładać biologiczne definicje do ludzkiego funkcjonowania oraz definicje i terminy opisujące zachowania ludzi do innych zwierząt, bo budzi to sprzeciw. Taki podział istnieje też w naukach bliższych przyrodniczym niż „czysta humanistyka” - wyodrębnia się np. etologię (badającą zachowania zwierząt) i psychologię (badającą zachowania ludzi). Rzadko udaje się więc bezpośrednio wykorzystać terminologię wykorzystywaną w biologii do opisywania relacji człowieka $z$ jego otoczeniem. Ponadto, relacje człowieka $z$ innymi bytami są bardzo zróżnicowane i bywają niejednoznaczne nawet wobec jednego gatunku (np. królik może mieć status zwierzęcia towarzyszącego, hodowlanego, laboratoryjnego czy szkodnika). Naszym celem w tym tekście jest próba podjęcia humanistycznej refleksji nad relacjami międzygatunkowymi: ludzi $\mathrm{i}$ innych istot żywych.

\section{Definiowanie relacji międzygatunkowych}

Ludzka świadomość, zdolność do abstrakcyjnego, zaawansowanego myślenia oraz możliwość niezwykle efektywnego przekształcania otoczenia są czynnikami, które w najbardziej znaczący sposób wpływają na to, że relacje człowieka $\mathrm{z}$ innymi gatunkami miewają odmienny charakter niż relacje pomiędzy przedstawicielami gatunków pozaludzkich. W odniesieniu do relacji międzygatunkowych rozumianych jako relacje ludzi i nie-ludzi pojawia się coraz bardziej dynamiczna i spolaryzowana dyskusja. Z jednej strony podkreśla się opresyjny i eksploatacyjny charakter nastawienia człowieka do otoczenia przyrodniczego, krytykowane są ludzkie praktyki mające na celu pozyskiwanie określonych gatunków (aż do ich całkowitego wytępienia), piętnowane są zjawiska takie jak masowa produkcja zwierzęca (z której jednak większość ludzi w ten lub inny sposób korzysta) oraz inwazyjność ludzkich działań dla otaczającej człowieka przyrody. Z drugiej zaś strony podnoszą się głosy o niezwykle pozytywnym 
wpływie relacji ludzko-nie-ludzkich na ludzi, mówi się o terapiach z udziałem zwierząt i emocjonalnych z nimi związkach, podnoszących jakość życia i dobrostan ludzi. Pionierskie zainteresowanie tymi zjawiskami w anglosaskim kręgu kulturowym spowodowało wykrystalizowanie się specyficznej terminologii, trudnej do przełożenia na inne języki, co widać w przypadku analizy pozytywnych relacji ludzi i istot nie-ludzkich. W języku angielskim, szczególnie w rozważaniach poświęconych pozytywnym aspektom kontaktów ludzi i nie-ludzi, używa się terminu bond ('kleić, łączyć' ale też 'więź') - zastosowanie podobnego określenia w języku polskim wydaje się trudniejsze. Być może adekwatny byłby termin „więź”, choć w polszczyźnie niesie on konotacje przede wszystkim trwałości związku. Inne określenia: „związek”, „relacja” nie przywołują tak jednoznacznie pozytywnych skojarzeń. Określenie „bond” zapożyczone zostało z psychoanalitycznych rozważań nad relacją dziecka i matki (opiekuna, znaczących „innych”). Opisuje ono związek podmiotów (Bowlby 2007) oparty na pozytywnych emocjach oraz pozwalający na zaspokajanie potrzeb obu stron, w którym jednocześnie istnieje nierównowaga sił, zasobów i możliwości działania. Tym samym staje się ono wektorem, za pomocą którego sposób opisywania relacji wewnątrzgatunkowych zostaje przeniesiony na relacje międzygatunkowe, tworząc pozór analogii. Pierwszy aspekt rozważań nad terminologią wzajemnych odniesień ludzi i nie-ludzi to zatem uwzględnienie całej gamy emocjonalnej, jaką mogą nieść te odniesienia. W The Companion Species Manifesto (Manifest gatunków stowarzyszonych), pisząc o tym, na czym mają jej zdaniem polegać badania feministyczne, Donna Haraway twierdzi, że opierają się one

na próbach zrozumienia, jak to [relacje] działa, kogo można odnaleźć w tym działaniu, co mogłoby być możliwe, i w jaki sposób ziemscy, materialni aktorzy mogliby stać się odpowiedzialni za siebie nawzajem i kochać się nawzajem w mniej okrutny sposób (Haraway 2012: 246).

Właśnie taki rodzaj relacji wzajemnej, w której mieszają się statusy i znaki emocji („kochać się mniej okrutnie”), można znaleźć w relacjach międzygatunkowych.

Drugi aspekt pojęcia relacji międzygatunkowych można opisać pytaniem: czy relacja zawsze oznaczać musi interakcję? Interakcja zakładałaby aktywność wszystkich stron układu, podczas kiedy relacja nie musi przecież być oparta na takim samym poziomie aktywności stron. Można mówić o relacji, gdy jedna strona podejmuje interakcję, a druga ją ignoruje, nie podejmuje aktywności albo nawet aktywnie unika interakcji. Czy na przykład egzystowanie obok siebie 
dwóch drzew jest już ich relacją? Kiedy relacja w ogóle się pojawia? Ludzie jako sprawcze podmioty często angażują w relacji dotyk - zmysł ważny dla ludzkiego poznania, ale niekoniecznie potrzebny do poznawania świata innym zwierzętom czy np. roślinom. W angażowaniu dotyku w relacje międzygatunkowe objawia się też często ludzka opresyjność wobec innych (nawet jeśli dotyk jest „tylko” głaskaniem) (Mamzer 2021).

Trzecim ważnym aspektem pojęcia relacji międzygatunkowych jest fakt, że człowiek nie zawsze musi w nich uczestniczyć, a więc adekwatne definicje powinny uwzględniać ten wariant i opisywać związki międzygatunkowe w sposób uniwersalny. Mimo że perspektywa antropocentryczna zawsze wprowadza w relacje człowieka jako głównego bohatera, świat ożywiony ma się doskonale bez homo sapiens.

Po czwarte - relacje międzygatunkowe to relacje nie tylko z proaktywnymi aktorami, jakimi są zwierzęta. To także relacje z roślinami, grzybami czy porostami - pozornie statycznymi i niereagującymi na otoczenie. To także relacje $\mathrm{z}$ organizmami, które formalnie, taksonomicznie zaliczane są do królestwa zwierząt, ale które w praktyce życia codziennego nie są nazywane zwierzętami - jak pajęczaki, owady i byty, które w ludzkiej świadomości występują jako „inne” (nie rośliny, ale również nie zwierzęta). Szeroko na ten temat pisze Dariusz Gzyra (2014), przywołując też innych autorów: „opowiadanie o zwierzętach wijących gniazda na drzewach nie byłoby rozpoznawane jako tekst o ptakach” (Tokarski 2002: 13). Badacze ci wskazują, że język odzwierciedla myślenie ludzi o świecie, a jak twierdził Ludwig Wittgenstein - granice języka są granicami poznania (Wittgenstein 2002: 64). Zawężające określenie: „relacje ludzko-nie-ludzkie" także jest niejednoznaczne. W różnych źródłach wskazuje się odmienne cechy uznawane za konstytutywne dla tegoż zjawiska, wymieniając pewne charakterystyki relacji międzygatunkowych, które w danym przypadku oddają specyfikę związku człowieka i innych bytów ożywionych (por. Gzyra 2014; Linzey, Cohen 2011; Tokarski 2002 i in.). Tego rodzaju próby zdefiniowania pojęcia pojawiają się w kontekście terapii i resocjalizacji z udziałem zwierząt, koncentrując się na pozytywnym (przede wszystkim dla człowieka) wymiarze relacji międzygatunkowych. Tworzenie definicji podkreślających pozytywny wymiar relacji także dla nie-ludzi ma nieść ze sobą imperatyw odpowiedniego traktowania zwierząt nie-ludzkich przez ludzi, ponieważ to oni, dysponując $\mathrm{w}$ urządzonym przez siebie świecie większą mocą podmiotowego działania, odpowiadają w większym stopniu za kształt relacji ludzko-nie-ludzkich. Mają więcej zasobów, więcej sprawczości i lepiej orientują się w antropocentrycznym świecie. $Z$ etycznego punktu widzenia odpowiedzialność powinna być lokowana zawsze po ludzkiej stronie, jako że zasoby i możliwości stron zaangażowanych $\mathrm{w}$ relacje nie są symetryczne. 
Autorzy podejmujący próby dookreślenia terminu „relacje międzygatunkowe" wskazują różne cechy istotne dla specyfiki tego zjawiska. I tak Jerrold Tannenbaum (1995) podkreśla jako istotne dla relacji człowieka $\mathrm{z}$ innymi gatunkami (w tym przypadku zwierzętami): ciągłość relacji, to, że relacja powinna być oparta na dobrowolności, oraz fakt, że musi ją cechować dwukierunkowość (wielokierunkowość w przypadku zaangażowania kilku podmiotów). Lily-Marlene Russow (2002) wskazuje, że taka relacja musi być oparta na wymianie, musi być trwała, a ponadto zwierzę nie-ludzkie musi rozpoznawać konkretnego człowieka. Jeśli zwierzę nie poznaje człowieka, nie można mówić o pełnej relacji międzygatunkowej. Takie rozważania mogą budzić wątpliwości, można bowiem przyjmować zero-jedynkowo, że relacja albo jest, albo jej nie ma, nie wprowadzając stopniowania, które ma wskazywać np. na istnienie „pełnych relacji” lub „niepełnych relacji” - jak proponuje Russow. Jednak Russow „cieniuje” relację: ocenia ją inaczej, jeśli tylko człowiek rozpoznaje zwierzę, i inaczej, kiedy człowiek i zwierzę rozpoznają się wzajemnie. Szczególnie istotne jest założenie, że po stronie zwierzęcia powinno się obserwować podniesiony poziom zaufania (problem budowania zaufania w relacjach ludzi z innymi zwierzętami jest szeroko analizowany w badaniach z zakresu dobrostanu zwierząt, zob. Rollin 2017, oraz szkolenia psów i koni: Ingold 1994; Brando 2012), po stronie człowieka zaś - większą troskę o zwierzę. Ten aspekt wydaje się bardzo inspirujący - jego sformułowanie wynika bowiem ze zrozumienia specyfiki gatunkowej człowieka i innych zwierząt. Russow nie buduje relacji równowagi w oparciu o prostą wymianę (obie strony muszą się rozpoznawać wizualnie), ale uwzględnia specyfikę gatunkową stron wchodzących w relację. Oczekiwanie od człowieka większej troski jest zasadne - w myśl twierdzeń zakładających, że jako byt o wysoko rozwiniętym intelekcie człowiek powinien przewidująco dbać o inne byty. $\mathrm{Na}$ podwyższony poziom odpowiedzialności zwierzę nie-ludzkie może odpowiadać jedynie wyższym poziomem zaufania. Definicja Russow akcentuje także wspomnianą wcześniej niesymetryczność relacji ludzko-nie-ludzkich: człowiek ma większą sprawczość i podmiotowość (którą sam sobie nadał, z czasem w pewnych zakresach przyznając ją innym gatunkom) oraz zdolność do świadomej i rozbudowanej eksploatacji innych gatunków - realizowanej w wymiarze niespotykanym w żadnych innych relacjach międzygatunkowych. Z kolei Alan M. Beck (1999) podkreśla obustronność korzyści podnoszących jakość życia stron wchodzących w relację. W jego rozważaniach uderza ukierunkowanie wyłącznie na relacje o charakterze pozytywnym - które wszak mogą istnieć tylko w utopijnym, nierealnym świecie bez dominacji.

American Veterinary Medical Association's Committee on the Human-Animal Bond proponuje przyjęcie definicji relacji międzygatunkowej rozumianej jako: 
Dynamiczna relacja niosąca wzajemne korzyści dla ludzi i innych zwierząt. Mają na nią wpływ zachowania niezbędne dla utrzymania zdrowia i dobrostanu obu stron. Obejmuje ona między innymi emocjonalne, psychologiczne i fizyczne interakcje ludzi, innych zwierząt i środowiska ${ }^{1}$ (cyt. za: Fine 2015: 5).

Podejście takie cechuje silny ładunek aksjologiczny. Oczywiście z punktu widzenia antropozoologii jest to definicja o brzmieniu sensownym i ważnym nakazuje bowiem, by ludzie wchodzący w relacje z przedstawicielami innych gatunków, jako strona mająca możliwość realizowania większej odpowiedzialności, dbali o te gatunki. Powyższe rozumienie koncentruje się wyłącznie na pozytywnych relacjach ludzi i nie-ludzi, co wynika z głównego przedmiotu zainteresowania stowarzyszenia, pomijając relacje o charakterze eksploatacji dotyczące zarówno zwierząt hodowlanych, jak i dzikich.

Jeszcze raz przywołując wspomnianą już Haraway i jej Manifest gatunków stowarzyszonych, należy wskazać ważną cechę relacji, w tym międzygatunkowych: nadają nowy sens bytom, które w nie wchodzą. Co prawda Haraway pisze o psach i ludziach, ale egzemplifikację tę można łatwo ekstrapolować na relacje między innymi gatunkami. Istotne jest to, że odrębne monady, wchodząc w relację, zyskują nowe jakości, cechy i sensy:

Nie może istnieć jeden gatunek stowarzyszony; aby go utworzyć, konieczne są co najmniej dwa. Na tym polega jego składnia; taka jest jego materia. Psy opowiadają nieuniknioną, pełną sprzeczności historię relacji - relacji współkonstytutywnych, w ramach których żaden z partnerów nie istnieje uprzednio wobec zaistnienia relacji, a związek nigdy nie zawiązuje się raz i na zawsze (Haraway 2012: 249).

To ważny element w relacjach międzygatunkowych - podnosi bowiem kwestie definiowania siebie także przez kontakt $\mathrm{z}$ innymi, również nie-ludzkimi. Taki relacyjny wymiar konceptualizowania podmiotów wchodzących w interakcję ugruntowuje ponadto myślenie o tożsamości jako o dynamicznym procesie, nie zaś statycznym fakcie.

1 "Mutually beneficial and dynamic relationship between people and other animals that is influenced by behaviors that are essential to the health and well-being of both. This includes, but is not limited to, emotional, psychological and physical interactions of people, other animals and the environment". Tłumaczenia tekstów, jeśli nie zaznaczono inaczej, pochodzą od autorek artykułu. 


\section{Relacje międzygatunkowe w socjologii}

Obecnie w socjologii możemy obserwować niezwykłą ambiwalencję analiz relacji ludzko-nie-ludzkich: od ujęcia zoocentrycznego i postantropocentrycznego, w którym dystans między tym, co ludzkie i nie-ludzkie, przestaje być dostrzegalny, po modernistyczne, antropocentryczne definiowanie socjologii jako badającej ludzki świat, w którym to, co nie-ludzkie, jest na tyle odległe, że staje się niemal niewidoczne w protokole badawczym (Gouabault, Burton-Jeangros 2010). Niełatwe relacje socjologii z biologią oraz jej założenia dotyczące wyjątkowego statusu człowieka czy też pojawienie się socjologii w kontekście industrializacji i urbanizacji są kluczem do zrozumienia braku uwagi poświęcanej zwierzętom w pierwszym stuleciu jej istnienia. Wspomniane okoliczności historyczne stworzyły podłoże do ugruntowania się w tej młodej wówczas dyscyplinie naukowej ograniczenia do konceptualizacji społeczeństwa jako tworu monogatunkowego (Carter, Nickie 2016), czego potwierdzenie stanowią analizy treści podręczników do socjologii (Alger, Alger 2003).

\section{Socjologia monogatunkowa}

Nie-ludzie są wielkimi nieobecnymi i wykluczonymi w narracjach klasycznych socjologów. Tłumaczy się to faktem, że socjologia jako nauka modernistyczna była dzieckiem antropocentrycznego pozytywizmu. Jej badawcza i teoretyczna uwaga przez ponad wiek ogniskowała się na relacjach panujących w świecie międzyludzkim. W kadrze dominującego socjologizmu nie-ludzkie istnienia zostały unieruchomione i pozbawione sprawczości lub sprowadzono je do antropomorfizujących projekcji człowieka w świecie, w którym panowało przekonanie o odrębności ludzkości od natury. Wyznaczone w XX wieku ramy nie dawały przestrzeni do analiz międzygatunkowej rzeczywistości. Głęboki antropocentryzm stał się tak znaczący, że aż niepodważalny, o czym świadczy stopień wpływu Émila Durkheima na socjologię oraz zakres antropocentryzmu w socjologii jako całości. Rdzenna dla teorii Durkheima koncepcja homo duplex oddzieliła ludzi od wszystkich innych zwierząt (co zresztą wcześniej na gruncie filozofii zrealizował Kartezjusz). Durkheim używał pojęcia homo duplex jako narzędzia ontologicznego. Dzięki niemu definiował ludzkość jako posiadającą unikalną zdolność do tworzenia i uczestniczenia w tym, co społeczne (Fish 2013; Łucka 2016). Teoretyczny dystans między człowiekiem a innymi gatunkami wywołał empiryczną niewidzialność tych drugich. W cieniu procesu budowania tożsamości socjologii jako dyscypliny naukowej w Europie dokonało się ubezwłasnowolnienie i zapomnienie zarówno świata przyrodniczego, jak i jego aktorów (Arluke 2002). W klasycznych narracjach socjologicznych 
występowali oni głównie jako „obiekty” ludzkich działań (Jarvikowski 1996: 82; Foster 1999; Foster, Holleman 2012), środowisko, w którym mają one miejsce albo manifestacja porządku aksjologicznego społeczeństwa.

Koncepcja socjologii zaproponowana przez Herberta Spencera wyłoniła życie społeczne człowieka jako element świata przyrody, jednak nie miała mocy, aby otworzyć przed socjologią możliwości włączania wiedzy o pokrewieństwach i stosunkach międzygatunkowych. Ewolucyjna perspektywa tego konceptu zamknęła drogę do badania związków i wymian zachodzących w międzygatunkowych praktykach społecznych (Kubik 1977, Szacki 2002). Ograniczeń ewolucjonizmu nie udało się uniknąć wyłonionej z nauk biologicznych socjobiologii. Skupiła się ona głównie na analizach relacji między biologiczną naturą człowieka a światem społecznym (Kośmicki 1994; Nilsen 1994; Łepko 2003).

\section{Socjologia relacji międzyzwierzęcych}

Relacje społeczne ze zwierzętami stanowiły potencjalne martwe punkty w teorii socjologicznej do lat siedemdziesiątych XX wieku (Arluke 2002; Hines 2003; Shapiro, DeMello 2010; Hosey, Melfi 2014). Zainteresowanie społeczną rolą zwierząt w socjologii wynikało w tym czasie ze zwiększonego zainteresowania społecznego kwestiami związanymi z żywieniem, opieką i ochroną innych gatunków. Zbiegło się także ze zdefiniowaniem epoki antropocenu. Rozwój badań poświęconych Human Animal Interaction (HAI) - a szczególnie pozytywnemu wpływowi na człowieka kontaktu ze zwierzętami - stymulowany był przez zapotrzebowanie na wiedzę płynące ze strony przemysłu żywieniowego zwierząt oraz sektora usług weterynaryjnych (Michalon, Doré, Mondémé 2016).

Równocześnie w socjologii nastąpił zwrot w kierunku badania praktyk życia codziennego oraz uwzględniania roli cielesności i natury w życiu społecznym. Prowadzone w tym czasie analizy wskazywały na zwierzęta nie-ludzkie jako mimowolnie osadzone w relacjach społecznych, szczególnie w pozytywnym aspekcie kontaktu człowieka ze zwierzętami (Michalon, Doré, Mondémé 2016). To z kolei wiązało się z redefinicją tego, co społeczne, i tego, co oznacza bycie człowiekiem, rewizją pojęć sprawczości, podmiotowości i refleksyjności oraz z odrzuceniem gatunkowości i antropocentryzmu, na których opierała się dotąd klasyczna socjologia. Powyższe tendencje pojawiły się głównie w socjologii anglosaskiej (Alger, Alger 1997; Myers 2003; Nibert 2003). Badając, czy i jak inne gatunki wchodzą w kluczowe procesy kształtujące jaźń i społeczeństwo, interakcjoniści symboliczni próbują określić sposoby, w jakie mogą one zostać włączone do głównego przedmiotu socjologii (Arluke 2002; Konecki 2005). Aby 
to wykazać, konieczne stało się ponowne przeanalizowanie i skorygowanie prac George'a Herberta Meada w świetle ostatnich badań nad wczesnym rozwojem człowieka oraz konceptualnych analiz języka, ciała i jaźni. Kształtowanie się jaźni nie jest zależne jedynie od wymiany językowej - niewerbalny nie-ludzki „inny” może przyczynić się do autorefleksyjnego poczucia bycia ludzkim „ja”. Janet M. Alger i Steven F. Alger (1997) argumentują, że ludzkie „ja” powinno być postrzegane jako zakorzenione w dostępnej wspólnocie mieszanych gatunków. Takie rozumowanie otwiera potencjał dla socjologii relacji międzygatunkowych.

W obszarze interakcjonizmu symbolicznego główną kwestią jest zakres językowo-pośredniczącej intersubiektywności człowieka i zwierzęcia. Interakcjonizm symboliczny stara się włączyć języki zwierząt i określić to, jak niektóre z nich przyswoiły sobie ludzki język, a także jak ludzie opanowują języki innych istot. Bada również, jak relacje międzygatunkowe reprezentują i kształtują wrażliwość współczesnego człowieka. Stosowanie etnografii w metodologii interakcjonistycznej pozwala socjologom i etologom analizującym światy międzygatunkowe na odnajdywanie i konstruowanie wspólnego języka badawczego (Barad 2007; Konecki 2005). Należy zaznaczyć, że część interakcjonistycznych studiów nad relacjami międzygatunkowymi ma charakter socjologii romantycznej, w której analizuje się symboliczne reprezentacje innych gatunków w świecie ludzkich znaczeń (Hałas 2001: 19-20). Zastosowanie etnografii interakcjonistycznej pozwala socjologom i etologom badającym zwierzęce światy międzygatunkowe na konstruowanie wspólnej, interdyscyplinarnej płaszczyzny metodologicznej. Ciekawość dotycząca społecznego życia innych gatunków i rozpoznanie sprawczości innych gatunków w procesach nadawania znaczeń wyznaczyło przestrzeń zwrotu zoocentrycznego drugiej połowy XX wieku (Arluke 2002; Myers 2003; Nibert 2003).

\section{Socjologia wielogatunkowa}

Socjologia może jednak podążać współcześnie jeszcze jedną, płodną empirycznie - ale trudną dla dotychczasowej tożsamości dyscypliny - drogą. Ścieżka ta domaga się zwrotu ontologicznego w socjologii i uznania sprawczej obecności tego, co nie-ludzkie i nie-zwierzęce. Actor Network Theory (ANT) odsłoniła społeczną sprawczość nie tylko istot ożywionych, ale też tych nieożywionych i transcendentalnych. Tym samym wprowadzono socjologię w myślenie posthumanistyczne i postantropocentryczne. Niemodernistyczna teoria Brunona Latoura (2010) związała na nowo to, co społeczne, w niezliczone domagające się badań i opisów kombinacje splotów. Polatourowska socjologia coraz częściej postrzega świat niedualnie, a jego reprezentacje jako sprawcze podmioty 
współtworzące doświadczenie i trajektorie życia społecznego. Opisuje typy solidarności międzygatunkowych, w których człowiek splata się z innymi istotami (zwierzętami, roślinami, maszynami) w formę hybrydy, wspólnoty bądź jako uczestnik wymiany. W pracach Latoura, Johna Lawa, Michela Callona (Kowalska 2010) i innych bada się hybrydową naturę świata społecznego (Callon 1984; Callon, Rip 1992). Podobnie prace „nowych materialistów”, takich jak Karen Barad i Rosi Braidotti, nawołują do zerwania z tym, co ich autorzy postrzegają jako konwencjonalne ontologie socjologiczne $\mathrm{z}$ antropocentrycznym ograniczeniem tego, co społeczne, do tego, co ludzkie i zwierzęce (Braidotti 2013: 14).

\section{Relacje międzygatunkowe: ludzie i inne byty}

We współczesnych próbach określenia definicyjnych ram dla relacji międzygatunkowych pojawia się kilka inspirujących wątków. Po pierwsze - kwestia fundamentów wiedzy naukowej. Okazuje się, że odrzucając granice i podstawy, poszerzamy swoje postrzeganie świata, a tym samym odnajdujemy (czy raczej uświadamiamy sobie) swoje miejsce we wszechświecie. Francisco J. Varela, Evan Thompson i Eleanor Rosch napisali w książce The Embodied Mind Cognitive Science and Human Experience (Nauka poznawcza ucieleśnionego umysłu i ludzkie doświadczenie):

Nasza podróż doprowadziła nas teraz do punktu, w którym możemy docenić, że to, co uznaliśmy za twardy grunt, tak naprawdę przypomina usuwanie się piasku pod stopami. Zaczęliśmy od zdrowego rozsądku jako kognitywiści i odkryliśmy, że nasze poznanie wyłania się z tła świata, który rozciąga się poza nas, ale którego nie można znaleźć poza naszą cielesnością. Kiedy odwróciliśmy naszą uwagę od tej fundamentalnej zależności, aby podążać za samym ruchem poznania, stwierdziliśmy, że nie możemy dostrzec żadnej subiektywnej podstawy, żadnej trwałej jaźni. Kiedy próbowaliśmy znaleźć obiektywną podstawę, o której myśleliśmy, że musi być nadal obecna, znaleźliśmy świat ustanowiony przez naszą historię połączeń strukturalnych. Wreszcie zobaczyliśmy, że te różne formy bezpodstawności są w rzeczywistości jednym: organizm i środowisko splatają się ze sobą i wpływają na siebie wzajemnie $w$ fundamentalnym obiegu, jakim jest samo życie ${ }^{2}$ (Varela, Thompson, Rosch 2016: 217, wyróż. - Ł.L.].

2 "Our journey has now brought us to the point where we can appreciate that what we took to be solid ground is really more like shifting sand beneath our feet. We began 
Takie holistyczne postrzeganie świata „przywraca” człowieka naturze, a naturę człowiekowi - doprowadza do ponownego scalenia, postrzegającego życie jako zbiór relacji o różnym natężeniu i charakterze. Nie ma istot żywych, z którymi ludzie nie są w „jakiejś” relacji. Sam fakt istnienia w określonej przestrzeni i czasie jest dowodem na te relacje, które mogą mieć charakter uświadomiony lub nieuświadomiony, być pozytywne lub negatywne, mogą wreszcie być wynikiem działania lub braku podjęcia jakichkolwiek działań. Takie rozumienie relacji międzygatunkowych całkowicie destabilizuje wszelkie poczucie pewności. Varela i współpracownicy zdają sobie sprawę z tego, że odnalezienie się w świecie „bez podstaw” (groundlessness) może być odbierane negatywnie, jednakże wyzbycie się podejścia antropocentrycznego i przyjęcie podejścia holistycznego otwiera przeżywany świat i czyni zeń ścieżkę i miejsce realizacji - miejsce, w którym relacje stanowią sedno poznania (Varela, Thompson, Rosch 2016: 233-234). Zalecane jest myślenie tak dalece wychodzące poza ego, że sięga ono krańców wszechświata. To już nie jest biocentryzm, to myślenie planetarne (nazywane również „kosmicznym holizmem”, zob. Steiner 2013: 195). Stawia ono przed ludźmi wyzwanie ucieleśnienia urzeczywistnionego braku podstaw w kulturze naukowej, ale także troski o innych, z którymi współtworzą świat (Varela, Thompson, Rosch 2016: 245). Wszystko jest zależne od siebie wzajemnie, co w rzeczy samej samorzutnie ustanawia relacje pomiędzy podmiotami. Ludzie żyją w symbiozie ze wszystkim, co ich otacza, i chociaż koncept ten znany jest $\mathrm{z}$ nauczania podstawowego, $\mathrm{z}$ trudem trafia do obiegu naukowego (innego niż nauki biologiczne), gdzie nadal królują wszelkiej maści wywyższania rodzaju ludzkiego, któremu oddaje się pole do działania i dyktowania charakteru interakcji. Lynn Margulis uważa, że problem wynika $\mathrm{z}$ braku rozpowszechnienia znaczenia słowa „symbioza”, tymczasem jesteśmy „symbiontami na symbiotycznej planecie”, a przynajmniej tak być powinno (Margulis 2001: 7). Relacje międzygatunkowe w tym kontekście są więc tożsame z życiem.

with our common sense as cognitive scientists and found that our cognition emerges from the background of a world that extends beyond us but that cannot be found apart from our embodiment. When we shifted our attention away from this fundamental circularity to follow the movement of cognition alone, we found that we could discern no subjective ground, no permanent and abiding ego-self. When we tried to find the objective ground that we thought must still be present, we found a world enacted by our history of structural coupling. Finally, we saw that these various forms of groundlessness are really one: organism and environment enfold into each other and unfold from one another in the fundamental circularity that is life itself". 
Drugi wątek związany jest z pierwszym (wynika zarówno z bezpodstawności, jak i z przejawiania troski) i dotyczy nazywania i nienazywania. Alexandra Horowitz (2020) podczas Brooks Congress wskazała, że w stosunku do innych bytów wykonujemy trzy czynności: a) musimy je nazwać (naming), by dokonać procesu oswojenia (ich lub siebie z nimi) i uczynić bytami zauważonymi; b) musimy uczynić je bardziej ludzkimi przez pokazanie podobieństwa do nas samych (un-naming); c) i wreszcie musimy ponownie uczynić je takimi, jakie są, przez zaprzeczenie podobieństwu do nas i zmianę ich nazwy (re-naming). Kwestia nazywania bytów innych niż ludzkie uważana jest za oczywistą nierówność (Borkfelt 2011: 118), stąd dwie kolejne czynności mają na celu okazanie szacunku i dostrzeżenie sedna danej istoty. Proces ten wskazuje, co możemy nazwać relacją świadomą i intencjonalną oraz jak kształtują się pozostałe $\mathrm{z}$ naszych relacji międzygatunkowych i kto jest partnerem/partnerką w tej relacji (lub dla kogo my jesteśmy partnerem/partnerką). To, że istoty nie-ludzkie są w posiadaniu pewnej sprawczości relacyjnej, nie jest już szczególnie zaskakujące. Możemy je postrzegać zarówno jako inicjujące relację świadomą i intencjonalną, jak i jako podmiot ludzkich relacji. Dostrzeżenie podmiotów relacji w roślinach, grzybach, owadach czy bakteriach wymaga jednak szczególnego otwarcia się na „innych”. Przyglądając się relacjom rdzennych społeczności do szeroko rozumianej natury, Matthew Hall (2011) zwraca uwagę na ukonstytuowanie innego typu relacji, która polega na odnajdywaniu pokrewieństwa (kinship) między bytami.

Problem polega na tym, że dla człowieka relacja pokrewieństwa jest trudna do zauważenia, a dla innych nie-ludzkich bytów jest ona prawdopodobnie czymś oczywistym. Czysto teoretycznie - byty te są bowiem bardziej wrażliwe i posiadają większą wolę, a tym samym łatwiej angażują się w harmonijne relacje pokrewieństwa. Również Robin Wall Kimmerer (2013) kładzie nacisk na pokrewieństwo, a przy okazji wyraża nadzieję, że otwartość i zaufanie, cierpliwość i wrażliwość urzeczywistnią poczucie łączności fizycznej i duchowej z naturą. Dla niej wszystkie inne byty są „więcej-niż-ludzkimi krewnymi” (more-than-human kin), a co za tym idzie - to ludzie uczą się od nich. Pokrewieństwo przejawia się na różnych poziomach, jednym z ważniejszych jest zdaniem Kimmerer właśnie poziom biologiczny. Kimmerer pisze: „Jakie to niesamowite, mieć takie pokrewieństwo z tymi roślinami, które odżywiają swoje dzieci komórkami tak podobnymi do tych, które pomogły wydać na świat moje córki”3 (Kimmerer 2003: 26). I chociaż spojrzenie oczami naukowczyni o rdzennym

3 "How amazing to have such kinship with these plants, who nourish their children with cells so like the ones that helped bring my daughters into the world". 
pochodzeniu może wydawać się infantylne, nienaukowe i kontrowersyjne, jest ono podstawą dokonywania reinterpretacji dotychczasowych świadomych sposobów budowania relacji z innymi bytami.

Wątek trzeci koncentruje się na postrzeganiu świata jako jedności - hybrydy, która funkcjonuje na określonych (aczkolwiek zmiennych) zasadach w konkretnym czasie i przestrzeni. W tym hybrydycznym świecie relacje istnieją nie tylko na linii człowiek - zwierzęta nie-ludzkie, ale również ze światem roślin (Hall 2011; Witzany, Baluška, red. 2012; Marder 2013), grzybów (Margulis, Sagan 200o), nieożywionej (jak ją postrzegamy) natury w postaci minerałów, kamieni, wody itd. (por. Emoto 2007; Negarestani 2018). Monica Gagliano stwierdza, że

[...] żaden człowiek nie może naprawdę odmówić roślinom ich roli jako opiekunów fizycznego i emocjonalnego istnienia człowieka. Jednak zgodnie z zachodnim hierarchicznym rozumieniem świata przyrody te nieruchome i niewrażliwe istoty są wyraźnie niżej w naturze w stosunku do zwierząt i (oczywiście) ludzi, a zatem są zepchnięte na dno piramidy życia [...].

[Tymczasem - Ł.L.] od tysiącleci rośliny były uważane za ożywione, wyższe i inteligentne istoty, uznawane za nauczycieli przez wiele kultur. Na przykład w obu Amerykach dziesiątki rdzennych grup nadal czczą rośliny ze względu na psychologiczny i duchowy wpływ, jaki wywierają [one - Ł.L.] na jednostki i społeczności ${ }^{4}$ (Gagliano 2018: 188-189).

Według Gagliano zaprzeczenie, w jakim trwa kultura zachodnia, przypomina niedojrzałość nastoletniej osoby, która nie dostrzega wszystkich powiązań i koncentruje się wyłącznie na uzewnętrznianiu swoich wyobrażeń i projekcji swoich złudzeń dotyczących świata (Gagliano 2018: 192-193). Jej zdaniem tłumaczy to występowanie nadużyć względem środowiska naturalnego oraz wszelkich destrukcyjnych zachowań - poznanie, kim jesteśmy i jak dopasowujemy się do natury, pozwala ukoić „młodzieńcze” poczucie rozpaczy i separacji,

4 " $[\ldots]$ no human being can truly deny plants their role as nurturers of the human physical and emotional subsistence. Yet according to the Western hierarchical understanding of the natural world, those motionless and insentient beings are clearly of an inferior nature to animals and (of course) humans, and are therefore relegated to the bottom of the pyramid of life. [...] For millennia, plants have been regarded as animated, superior intelligent beings, honoured as teachers by many cultures. In the Americas for instance, dozens of indigenous groups still revere plants for the psychological and spiritual impacts they have on both individuals and communities". 
daje możliwość przejścia do dorosłości i zrozumienia swojego miejsca. Osiągnięcie takiego stanu „oświecenia” wymaga od ludzi pracy i dojrzałości, która dostrzega wszelkie istnienie i własne z nim powiązania. Istotą tego stanu jest uświadomienie wyjątkowości wszystkich bytów - ich inteligencji, umiejętności komunikacji, posiadania emocji itd., bo - jak piszą Gunter Witzany i František Baluška, „język i komunikacja nie są wynalazkami ludzkimi ani nie są (jak często się twierdzi) antropomorficznymi adaptacjami opisującymi nie-ludzką żywą naturę"s (Witzany, Baluška, red. 2012: vi). Matthieu Ricard uważa, że „biosfera jako całość rządzi się zasadą współzależności: ponieważ ewoluując razem, gatunki roślin i zwierząt są ściśle od siebie zależne, jeśli chodzi o przetrwanie"6 (Ricard 2016: 22).

Postrzeganie relacji między człowiekiem a innymi gatunkami przez pryzmat przytoczonych wątków pozwala dostrzec, jak szeroki mają one zakres. Nie tylko określają interakcję (czyli świadomą, intencjonalną lub bierną relację) z „innym", określają również ramy przestrzeni i czasu czy reakcji danego organizmu na bodźce (nie zawsze uświadomione relacje). Relacja może przebiegać jako „relacja do” (relations to) i „relacja z” (relations with), czyli może przejawiać się w stosunku do czegoś, angażując emocje i uczucia, jak i wskazując na aktywnośćl czynność bycia w relacji. Związki pomiędzy podmiotami wyznaczają charakter relacji - świat bez relacji nie jest więc możliwy. Hybrydowa ontologia relacyjna człowieka i innych bytów zaburzona przez kultywowanie "niedojrzałości”, o której pisała Gagliano (2018), i technicyzację, możliwa jest do odtworzenia czy uświadomienia przez zrozumienie swojego pokrewieństwa ze światem. Zdaniem Hartmuta Rosy „nowoczesność jest rozstrojona” (Rosa 2019: 1329), nie znaczy to jednak, że nie jest możliwy inny sposób bycia w świecie i inna forma odnoszenia się do tego świata wraz z obecnymi w nim bytami innymi niż ludzkie.

\section{Podsumowanie}

Niesymetryczność międzygatunkowych związków człowieka i innych bytów wydaje się ich cechą podstawową: trudno bowiem mówić o jakimkolwiek rodzaju „ekwiwalentnej” wymiany, w której strony wnoszą porównywalne jakości. Ta bazowa niesymetryczność wynika ze zróżnicowania specyfik gatunkowych.

5 "Language and communication are not inventions of humans, nor are they (as often claimed) anthropomorphous adaptations to describe the non-human living nature".

6 "The biosphere as a whole is ruled by the principle of interdependence: having evolved together, vegetable and animal species depend closely on one another for survival". 
Wszyscy wchodzimy w interakcje $z$ innymi gatunkami jako podmioty, jednocześnie zyskując w nich nowe tożsamości. Nie zawsze jednak kontakty międzygatunkowe są nacechowane pozytywnie; przemoc, konkurowanie i walka o zasoby również są elementami życia i nie sposób ich wyeliminować z perspektywy myślenia o dynamicznym współistnieniu różnych podmiotów. Współistnienie przedstawicieli różnych gatunków stanowi „dialogiczną” formę wydobywania na powierzchnię tożsamości bytów je tworzących. Oznacza to, że same relacje międzygatunkowe należy rozumieć jako dynamiczne formy reagowania przedstawicieli różnych gatunków z całym spektrum emocji - od odczuwanych jako pozytywne do tych odczuwanych jako negatywne. Tym bardziej że to, co w przypadku przedstawiciela jednego gatunku niesie koszt, stanowić może zysk dla przedstawiciela innego gatunku. W przypadku kontaktów międzygatunkowych z udziałem ludzi trzeba brać pod uwagę naszą odpowiedzialność za przyrodę wynikającą z tego, że dzięki poznawczym kompetencjom i zdolności abstrakcyjnego myślenia powinniśmy być w stanie przewidywać skutki naszego działania i podejmować kroki realizowania zrównoważonego rozwoju. Odpowiedzialność, jaka spoczywa na człowieku jako gatunku ze względu na te zdolności myślenia, powoduje, że nasze relacje $z$ innymi gatunkami nigdy nie będą symetryczne.

\section{| Bibliografia}

Alger Janet M., Alger Steven F. (1997), Beyond Mead, Between Humans and Felines, „Society and Animals”, nr 5(1), s. 66-81.

Alger Janet M., Alger Steven F. (2003), Drawing the line, „International Journal of Sociology and Social Policy", nr 23 (3), s.69-93.

Arluke Arnold (2002), A Sociology of Sociological Animal Studies, „Society and Animals", nr 10(4), s. 369-374.

Barad Karen (2007), Meeting the Universe Halfway, Quantum Physics and the Entanglement of Matter and Meaning, Duke University Press, Durham.

Beck Alan M. (1999), Companion Animals and Their Companions: Sharing Strategy for Survival, „Bulletin of Science, Technology \& Society”, nr 19(4), s. 281-285.

Borkfelt Sune (2011), What's in a Name? - Consequences of Naming Non-Human Animals, „Animals”, nr 1, s. 116-125.

Bowlby John (2007), Przywiązanie, przeł. Magdalena Polaszewska-Nicke, Wydawnictwo PWN, Warszawa. 
Braidotti Rossi (2013), Posthuman Humanities, „European Educational Research Journal", nr 12(1), s. 1-19.

Brando Sabrina I.C.A. (2012), Animal Learning and Training: Implications for Animal Welfare, „Veterinary Clinics of North America: Exotic Animal Practice", nr 15(3), s. 387-398.

Callon Michel (1984), Some Elements of a Sociology of Translation: Domestication of the Scallops and the Fishermen of St Brieuc Bay, „The Sociological Review”, nr 32(1), s. 196-233.

Callon Michel, Rip Arie (1992), Humains and non-humains: morale d'une coexistance, w: La Terre outragée: les experts sont formels!, red. Jacques Theys, Bernard Kalaora, Editions Autrement, Paris, s. 140-156.

Carter Bob, Nickie Charles (2016), The animal challenge to sociology, „European Journal of Social Theory", https://tinyurl.com/wa57peh3 [dostęp: 25.03.2021].

Emoto Masaru (2007), The Shape of Love, przeł. Noriko Hosoyamada, Doubleday, New York.

Fine Audrey H., red. (2015), Handbook on Animal Assisted Therapy. Foundation and Guidelines for Animal-Assisted Interventions, Elsevier, New York.

Fish Johnatan S. (2013), Homo duplex Revisited: A Defence of Émile Durkheim's Theory of the Moral Self, „Journal of Classical Sociology”, nr 13(3), s. 338-358.

Foster John-B. (1999), Marx's Theory of Metabolic Rift: Classical Foundations for Environmental Sociology, „American Journal of Sociology”, nr 105(2), s. 366-405.

Foster John B., Holleman Hannah (2012), Weber and the Environment: Classical Foundations for a Postexemptionalist Sociology, „American Journal of Sociology", nr $117(6)$, s. 1625-1673.

Gagliano Monica (2018), Persons as Plants: Ecopsychology and the Return to the Dream of Nature, w: Covert Plants. Vegetal Consciousness and Agency in an Anthropocentric World, red. Prudence Gibons, Baylee Brits, Brainstorm Books, Santa Barbara, s. 183-194.

Gouabault Emmanuel, Burton-Jeangros Claudine (2010), Lambivalence des relations humain-animal Une analyse socio-anthropologique du monde contemporain, „Sociologie et Sociétés”, t. 42(1), s. 299-324.

Gzyra Dariusz (2014), Problem zwierząt. Jak postrzegamy i jak traktujemy zwierzęta?, „Jednak Książki. Gdańskie Czasopismo Humanistyczne”, nr 2, s. 9-24.

Hall Matthew (2011), Plants as Persons. A Philosophical Botany, State University of New York, New York.

Hałas Elżbieta (2001), Symbole w interakcji, Oficyna Naukowa, Warszawa.

Haraway Donna (2012), Manifest gatunków stowarzyszonych, przeł. Joanna Bednarek, w: Teorie wywrotowe. Antologia przekładów, red. Agnieszka Gajewska, Wydawnictwo Poznańskie, Poznań, s. 241-26o. 
Hines Linda (2003), Historical Perspectives on the Human-Animal Bond, „American Behavioral Scientist", nr 47(1), s. 7-15.

Hosey Geoff, Melfi Vicky (2014), Human-Animal Interactions, Relationships and Bonds: A Review and Analysis of the Literature, „International Journal of Comparative Psychology", nr 27(1), s. 117-142.

Horowitz Alexandra (2020), Un-naming and Re-naming Animals, Brooks Congress Keynote Transcript, https://tinyurl.com/55crvc5w [dostęp: 25.03.2021].

Ingold Tim (1994), From Trust to Domination: An Alternative History of Human-Animal Relations, w: Animals and Human Society: Changing Perspectives, red. Aubrey Manning, James Serpell, Routledge, London, s. 1-22.

Jarvikoski Timo (1996), The Relation of Nature and Society in Marx and Durkheim Sociology, „Acta Sociologica”, t. 39(1), s. 73-86.

Kimmerer Robin Wall (2003), Gathering Moss. A Natural and Cultural History of Mosses, Oregon State University Press, Corvallis.

Kimmerer Robin Wall (2013), Braiding Sweetgrass. Indigenous Wisdom, Scientific Knowledge and the Teachings of Plants, Milkweed Editions, Washington.

Knight John (2018), Human-Animal Relations, w: International Encyclopedia of Anthropology, red. Hilary Callan, Wiley Blackwell, New York, s. 1-7, https://tinyurl.com/5b9axcxm [dostęp: 25.03.2021].

Kubik Włodzimierz (1977), Socjologia Herberta Spencera, „Przegląd Socjologiczny", nr 29, s. 339-348.

Konecki Krzysztof (2005), Ludzie i ich zwierzęta. Interakcjonistyczno-symboliczna analiza społecznego świata właścicieli zwierząt domowych, Wydawnictwo Scholar, Warszawa.

Kośmicki Eugeniusz (1994), Socjobiologia - nauka o społecznych zachowaniach człowieka i zwierząt, „Przegląd Antropologiczny”, nr 57(1-2), s. 107-112.

Kowalska Agnieszka (2010), Wspólnota poszerzona - spotkania ludzkich i pozaludzkich aktorów, „Praktyka Teoretyczna”, nr 1, s. 116-136.

Latour Bruno (2010), Splatają na nowo to, co społeczne. Wprowadzenie do teorii aktora-sieci, Universitas, Kraków.

Linzey Andrew, Cohen Priscilla N. (2011), Terms of Discourse, „Journal of Animal Ethics", t. 1, nr 1, s. VII-IX.

Łepko Zbigniew (2003), Spór o socjobiologię klasyczną, „Studia Ecologiae i Bioethicae", nr 1, s. 223-230.

Łucka Daria (2016), Émile Durkheim jako prekursor komunitaryzmu, „Studia Socjologiczne", nr 1(220), s. 7-35.

Mamzer Hanna (2021), Zgubne skutki wymuszanych relacji międzygatunkowych, „Zoophilologica. Polish Journal of Animal Studies”, nr 7/21, (w druku).

Marder Michael (2013), Plant-Thinking. A Philosophy of Vegetal Life, Columbia University Press, New York. 
Margulis Lynn (2001), The Symbiotic Planet. A New Look at Evolution, Phoenix, London.

Margulis Lynn, Sagan Dorion (2000), What Is Life, Berkeley, University of California Press, Los Angeles.

Michalon Jerome, Doré Antoine, Mondémé Chloé (2016), Une sociologie avec les animaux, faut-il changer de sociologie pour étudier les relations humains/ animaux?, „SociologieS. Dossiers, Sociétés en Mouvement, Sociologie en Changement", https://tinyurl.com/wrwudkwy [dostęp: 25.03.2021].

Myers Oline Eugene (2003), No Longer the Lonely Species: A Post-Mead Perspective on Animals and Sociology, „International Journal of Sociology and Social Policy", nr 23(3), s. 46-68.

Negarestani Reza (2018), Intelligence and Spirit, Urbanomic, Falmouth.

Nilsen François (1994), Sociobiology and sociology, „Annual Review of Sociology", nr 20, s. 267-303.

Nibert Daniel (2003), Humans and Other Animals: Sociology's Moral and Intellectual Challenge, „International Journal of Sociology and Social Policy”, nr 23(3) s. 4-25.

Ricard Matthieu (2016), A Plea for the Animals. The Moral, Philosophical, and Evolutionary Imperative to Treat All Beings with Compassion, przeł. Sherab Chödzin Kohn, Shambhala, Boulder.

Rollin Bernard (2017), Ethical Behavior in Animals: The Ethics of Companion Animals, w: Pets and People: The Ethics of Companion Animals, red. Christine Overall, Oxford University Press, New York, s. 95-110.

Rosa Hartmut (2019), Resonance. A Sociology of Our Relationship to the World, przeł. James C. Wagner, Polity Press, Cambridge.

Russow Lily-Marlene (2002), Ethical Implications of the Human-Animal Bond, „International League of Associations for Rheumatology”, nr 43(1), s. 33-37.

Steiner Gary (2013), Animals and the Limits of Postmodernism, Columbia University Press, New York.

Shapiro Kenneth J., DeMello Margo (2010), The State of Human-Animal Studies, "Society and Animals", nr 18(3), s. 307-318.

Szacki Jerzy (2002), Historia myśli społecznej, Państwowe Wydawnictwo Naukowe, Warszawa.

Tannenbaum Jerrold (1995), In Veterinary Ethics: Animal Welfare, Client Relations, Competition and Collegiality, Mosby, St. Louis MO.

Tokarski Ryszard (2002), Konceptualizacja zwierząt w potocznej świadomości językowej, w: Prawna ochrona zwierząt, red. Marek Mozgawa, Verba, Lublin, s. 11-14.

Varela Francisco J., Thompson Evan, Rosch Eleanor (2016), The Embodied Mind Cognitive Science and Human Experience, The MIT Press, Massachusetts. 
Wittgenstein Ludwig (2002), Tractatus logico-philosophicus, przeł. Bogusław Wolniewicz, PWN, Warszawa.

Witzany Guenther, Baluška František, red. (2012), Biocommunication of Plants, Springer Verlag, Berlin.

\section{| Abstrakt \\ Hanna Mamzer, Magdalena Anita Gajewska, Łucja Lange Jak rozumieć relacje międzygatunkowe?}

Pojęcie relacji międzygatunkowych wydaje się zdroworozsądkowo zrozumiałe. Kiedy jednak przyjrzeć mu się dokładniej, okazuje się, że niesie ono wiele różnych niuansów i niejednoznaczności. W niniejszym tekście przedstawiamy rozważania na temat sensu pojęcia - tego, że odnosi się ono do różnych emocji (relacji o charakterze pozytywnym i opresyjnym), że dotyczy zróżnicowanych aktorów (ludzie, zwierzęta, rośliny i inne byty), że nie jest statyczne, ale dynamiczne. Badamy, jak o ile w ogóle - to pojęcie mieściło się w klasycznych socjologiach: Émila Durkheima czy Herberta Spencera. Wskazujemy, że analizowanie relacji międzygatunkowych wymaga holistycznego i biocentrycznego (wręcz planetarnego) ujmowania świata, w którym uwzględnia się tak dyskurs naukowy, jak i pozanaukowy. Takie podejście pozwala na odnajdywanie pokrewieństwa (kinship) między bytami.

Słowa kluczowe: ludzie - nie-ludzie, relacje międzygatunkowe, kosmiczny holizm, pokrewieństwo

\section{| Abstract}

Hanna Mamzer, Magdalena Anita Gajewska, Łucja Lange Explorations in the Search of Answers on Understanding Notion of Interspecies Relations

The concept of interspecies relations seems to be clear according to common sense knowledge. However, upon a closer look, it turns out that it carries many different nuances and ambiguities. In this article, we present reflections on the meaning of the concept - that it relates to various emotions (positive and oppressive relationships), that it concerns various actors (people, animals, plants and other beings), that it is not static, but dynamic. We indicate how - if at all - this concept fits into 
the classical sociologies of Émila Durkheim or Herbert Spencer. We point out that analyzing interspecies relations requires a holistic and biocentric (even planetary) approach to the world in which both scientific and non-scientific discourses are taken into account. This kind of approach allows finding kinship between beings.

Keywords: humans-non-humans, interspecies relations, cosmic holism, kinship

\section{| Biogramy}

Hanna Mamzer - dr hab., prof. UAM w Zakładzie Socjologii Cywilizacji, psycholożka i socjolożka. Biegła sądowa przy Sądzie Okręgowym w Poznaniu w dziedzinie: dobrostan zwierząt i relacje człowieka z psem. Członkini Lokalnej Komisji Etycznej ds. Eksperymentów na Zwierzętach przy Ministrze Nauki i Szkolnictwa Wyższego. Stypendystka Fundacji Fulbrighta, Central European University, British Council, wielokrotna stypendystka Programu Socrates Erasmus, European University Institute we Florencji, Fundacji im. Stefana Batorego, laureatka akcji stypendialnej Polityki i wielu innych wyróżnień. Prowadzi szeroko zakrojoną współpracę międzynarodową - wykłada w Polsce i za granicą, przede wszystkim w USA. Członkini Polskiego Towarzystwa Socjologicznego, sekcji Socjologii Relacji Międzynarodowej. E-mail: mamzer@amu.edu.pl

ORCID: 00oo-0002-2251-7639

Magdalena Anita Gajewska - dr, absolwentka Uniwersytetu Gdańskiego w zakresie filozofii i socjologii. Członkini Polskiego Towarzystwa Socjologicznego, sekcji Socjologii Relacji Międzynarodowej. W 2004 roku była stypendystką rządu francuskiego. Autorka książki Kremacja ciała zmarłego człowieka jako zjawisko społeczne i fenomen kulturowy. Aktualnie pracuje w Instytucie Socjologii Uniwersytetu Gdańskiego w zakładzie Socjologii Życia Codziennego. Jako dydaktyk współpracuje od 12 lat z Gdańskim Uniwersytetem Medycznym.

E-mail: magdalena.gajewska@ug.edu.pl

ORCID: 000o-0002-4132-2132

Łucja Lange - mgr, doktorantka w Instytucie Socjologii Uniwersytetu Łódzkiego oraz Instytucie Badań Literackich PAN. Pracownica naukowa Uniwersytetu Łódzkiego. Absolwentka teatrologii i etnologii. Zajmuje się szeroko pojmowanymi obszarami animal studies, death studies i gender studies. Bada doświadczenie żałoby rodziców i patografie nowotworowe w sieci. Członkini Polskiego Towarzystwa Socjologicznego, sekcji Socjologii Relacji Międzynarodowej oraz Instytutu Dobrej Śmierci.

E-mail: LangeL@o2.pl

ORCID: 0000-0002-2676-1022 